Journal of Educational Method and Technology Vol. 2 No. 2, Agustus 2019

P-ISSN 2622-8459 E-ISSN 2622-8467

http://ejournal.unima.ac.id/index.php/jemtec

\title{
Reality Show: The Influence of Destination Exposure to Viewers' Travel Intention
}

\author{
S R Mege ${ }^{1}$ \\ Universitas Diponegoro, Indonesia \\ corresponding author: ${ }^{1}$ staciareviany@live.undip.ac.id
}

\begin{abstract}
Abstrak. Reality show has started to dominate the television industry and has been used as media for product placement strategy. Destination placement in reality show serves the same purpose. However, previous study in destination placement in reality show is limited, as well as the study about travel intention to destination through reality show. The purpose of this study is to examine the influence of destination exposure in reality show to viewers' travel intention to the destination. This study was conducted using experimental method, involving one hundred and four undergraduate students distributed randomly into experiment and control group. The stimulus used in this study was the popular reality show, The Amazing Race. The data was analyzed using independent sample t-test. The result of this study showed that in general viewers who received exposure of destination in reality show had higher travel intention to the destination, and in specific triggered the awareness and interest to look for information about the destination.
\end{abstract}

\section{Introduction}

Tourism is undoubtedly one of the most important aspect for a country. In the report of Economic Impact of Travel and Tourism (2019), it is stated that tourism industry contributes 10.4 per cent of global GDP, implies an increase of 1.4 per cent since 2016. The data also suggests that one fifth of the total global net job created within the travel and tourism sector and there are three hundred and nineteen million jobs are supported by travel and tourism (WTTC, 2019).

Year of 2018 is the second-best year since 2010 in terms of international tourist arrivals in which its experienced increase of six per cent to 1.4 billion arrivals. (UNWTO, 2019). Middle East and Africa lead the growth with 7.3 per cent and 10.3 per cent respectively. The overall results were driven by favorable economic environment, strong outbound from main markets, recovery in key destinations, better air connectivity that really helps international travel, and last but not least is visa facilitation (UNWTO, 2019). This data shows how important travel and tourism to a country and by the same reason motivates the government to promote their tourism around the world (Lee \& Chang, 2007; Nirwandar, 2014). Travelling is classified as high-involvement purchases (Dimanche \& Andrades, 2015) because from financial point of view, someone will have to spend quite amount of money to perform the activity (Kerstetter dan Cho, 2004). Hence, awareness and information 
about a destination is needed to help the potential travelers to make decision to go to the destination (Dimanche \& Andrades, 2015; Kerstetter dan Cho, 2004).

Tourism is strongly related to media, because media serves as sources of information for the travelers (Kumar 2014). Different kind of media have been used to promote tourism as well as to find information from. Starting from the very traditional one, travel brochure (Brito dan Pratas, 2015), travel blog (Lin dan Huang, 2006), travel related website such as Trip Advisor (Nezakati, Amidi, Jusoh, Moghadas, Aziz, dan Sohrabinezhadtalemi, 2015), film (Mackay dan Fesenmaier, 1997; Connell, 2005; Riley dan Von Doren, 1992; Tooke dan Baker, 1996; Riley, Baker, dan Von Doren, 1998; Kim dan Richardson, 2003; Shani, Wang, Hudson, dan Gil, 2009; Hudson, Wang, dan Gil, 2011), up to social media (Zeng dan Gerritsen, 2014).

Reality show is one of various type of TV programs or media in which involves real activities perform by individuals as their true self (Nabi, Biely, Morgan, and Stitt, 2003). There is limited research in regard to tourism promotion through reality show. The research of Tessitore, Pandelaere, and Van Kerckhove (2014) examined a Dutch reality show and the change in their perception towards the destination image and also the change in the travel intention to the destination. Other study investigated about popular reality show from Korea and how the involvement of audience influence travel intention to the destination (Fu, Ye, and Xiang, 2016).

This research however serves slightly different stimuli than the previous two research. In both reality shows used as stimuli, there were celebrities involved as shows' participants. Even though they were considered as reality shows, but the involvement of celebrities or public figures reduced the clarity of real people portraying their own character as mentioned by Nabi et al., (2003). This paper focuses on the travel intention to the destination, specifically to investigate whether there is difference in travel intention if viewers are exposed to the destination on reality show.

\section{Literature Review \\ Travel Intention}

In literal, travel intention describes someone's intention or commitment to travel to a certain destination (Jang, Bai, Hu, Wu, 2009). Having intention or desire can trigger an individual to make a decision to satisfy the need, that will lead to action or actual behavior, including travel intention (Fishbein dan Azjen, 1975; Jang, Bai, $\mathrm{Hu}, \mathrm{Wu}, 2009$; Jang and Namkyung, 2009).

Sources of information such as advertisements can help forming the destination image as well as affecting individuals' intention to visit the destination (Zhang, Fu, Cai, and Lu, 2014). Previous research on film tourism make researchers believe that portraying or displaying destination, place, whether city or country, can increase interest about the destination (Tooke dan Baker, 1996) and furthermore increase the intention to visit the destination (Riley et al., 1998; Riley dan van Doren, 1992

Croy and Walker (2003) argue that regardless of the genre, if someone see a destination or place in a movie, that person will have intention to visit the destination. It is supported by the finding of Shani et al., (2009) dan Hudson et al., 
Journal of Educational Method and Technology Vol. 2 No. 2, Agustus 2019

P-ISSN 2622-8459 E-ISSN 2622-8467

http://ejournal.unima.ac.id/index.php/jemtec

(2011) that used negative genre movie in the research but still resulted in high travel intention.

Refuse to stop only in movie, TV serials and other form of TV programs also serve the same impact as movie, shown in Kim et al., (2007) finding about the destination in South Korea.

\section{Reality Show and Destination Placement in Reality Show}

Reality show is a breakthrough in television industry (Barton, 2009) and starting to dominate the industry since a few years ago. This kind of program does not only involve celebrities in it, but also audiences or commoners (Wong, 2001) who perform real activities (Nabi, Biely, Morgan, and Stitt, 2003). Researchers have studied reality show to see the psychological tricks they offer to viewers (Nabi et al., 2003); application of uses and gratification theory in which a media user actively choose and use the media (Papacharissi et al., 2007; Blumler dan Katz, 1974); investigation of how do viewers enjoy reality show by disposition theory (Barton and Raney, 2002).

Destination placement in reality show has same concept with product placement in either movie or reality show. However, there is limited study about destination placement in reality show. So far, there are only two studies found. The first one was the study about on India Celebrity Express by Tessitore et al., (2014). Participants in the research were university students in Belgium and they were found to have higher travel intention to India after being exposed to reality show. The second research was the study conducted by Fu, Ye, Xiang (2016). They used audience involvement theory to investigate how does a reality show affect someone's perception about a destination. The finding states that audience involvement affects behavioral intention mediated by cognitive and affective image.

\section{Methods \\ Design}

This research was conducted to answer the research question: "Is there any difference in travel intention to the destination, between viewers and non-viewers?" This research question is congruous with the previous research by Tessitore et al., (2014) which also conducted experimental study to answer the question. We conducted an experimental study by applying between group design. Participants were undergraduate students and randomly distributed into experiment and control group. Participants in experiment group were asked to complete the questionnaire after receiving the stimulus, while the control group participants filled the questionnaire without receiving any stimulus.

\section{Stimuli}

After considering some reality shows run on $\mathrm{TV}$, researcher decided to use The Amazing race as the stimulus. The Amazing Race is a reality show where the contestants compete each other to become the final winner by the end of the season. Every week, the contestants will visit different countries across the world. This show is chosen as the stimulus because the contestants are not celebrities, hence reduce the possibilities of fake reaction or activities. The Amazing Race Season 27 episode 5 is specifically used because it was taken place in Zimbabwe, southern Africa to reduce 
the probability of previous visit. In this episode, contestants are challenged to walk the lion, feed the crocodile, and take a big swing at Batoka Gorge.

\section{Procedure}

Undergraduate students from a university in North Sulawesi, Indonesia were recruited to participate in this study. One hundred and four students were randomly distributed into experiment and control group. The procedure in each group was started by brief explanation from researcher and followed by distribution of informed consent form. Participants in experiment group then watched the video stimulus. They were asked to complete the questionnaire after being exposed to the stimulus, meanwhile those in control group were asked to complete it directly. The last step was the debriefing from researcher about the true purpose of this research.

\section{Measurement}

The measurement of travel intention to the destination was adopted from Shani et al., (2009) which consisted of four questions as follows: "I am aware of Zimbabwe as a suitable tourism destination", "I'm interested in getting more information about Zimbabwe", "I have desire to visit Zimbabwe", and "I will book a vacation to Zimbabwe". They are measured on a seven-point Likert Scale $(1=$ "totally disagree" and $7=$ "totally agree). To make sure the participants received the stimulus, there was manipulation check. The manipulation check consisted of four multiple choice questions and two open ended questions.

\section{Analytical Method}

Researcher used independent sample t test to analyze the result. Indepent sample $t$ test is used to compare experiment group and control group.

\section{Results and Discussions \\ Results}

Travel intention is an important construct in tourism research. According to Jang \& Namkyung (2009) the action of tourists will follow the intention and motivation to visit the destination they have in the first place. In this study, researcher believed that by receiving exposure of video stimulus of the destination, there will be differences in travel intention between experiment and control group, specifically higher in experimental one.

Table 1. Independent Sample T Test on Travel Intention

\begin{tabular}{|l|l|l|l|l|l|}
\hline $\begin{array}{l}\text { Travel } \\
\text { Intention }\end{array}$ & $\begin{array}{l}\text { Before } \\
\text { Mean } \\
(\mathrm{SD})\end{array}$ & $\begin{array}{l}\text { After } \\
\text { Mean } \\
(\mathrm{SD})\end{array}$ & $\begin{array}{l}\text { Mean } \\
\text { Difference } \\
(\mathrm{SD})\end{array}$ & DF & T-value (sig) \\
\hline TI1 & $4.76(1.44)$ & $3.00(1.34)$ & 1.76 & 101 & $6.437(.000)^{* * *}$ \\
\hline TI2 & $4.30(1.79)$ & $3.55(1.80)$ & .75 & 101 & $2.125(.035)^{*}$ \\
\hline TI3 & $4.12(1.98)$ & $4.00(2.17)$ & .12 & 101 & $.290(.772)$ \\
\hline TI4 & $3.34(1.75)$ & $3.10(1.86)$ & .24 & 101 & $.678(.499)$ \\
\hline $\begin{array}{l}\text { Composite } \\
\text { TI }\end{array}$ & $\mathbf{4 . 1 3 ( 1 . 5 9 )}$ & $\mathbf{3 . 4 1}(\mathbf{1 . 5 2})$ & $\mathbf{. 7 2}$ & $\mathbf{1 0 1}$ & $\mathbf{2 . 3 4 5 ( . 0 2 1 ) ^ { * }}$ \\
\hline \multicolumn{2}{|l}{$* \mathrm{p} \leq .05 ; * * \mathrm{p}<0.01$} & & &
\end{tabular}


Journal of Educational Method and Technology Vol. 2 No. 2, Agustus 2019

P-ISSN 2622-8459 E-ISSN 2622-8467

http://ejournal.unima.ac.id/index.php/jemtec

In table 1, we can see that the mean score for all four indicators in experiment group were higher than in control groups. Indicator $\mathrm{TI} 1 \mathrm{M}_{\mathrm{TIl}}$ experiment $=4.76$; $\left.\mathrm{M}_{\mathrm{TI} 1 \text { control }}=3.00 ; p=.000\right)$ and TI2 $\left(\mathrm{M}_{\mathrm{TI} 2 \text { experiment }}=4.30 ; \mathrm{M}_{\mathrm{TI} 2 \text { control }}=3.55 ; p=.036\right)$ are significantly different between experiment and control group. Meanwhile the next two indicators, TI3 ( $\mathrm{M}_{\text {TI3experiment }}=4.12 ; \mathrm{M}_{\mathrm{TI} 3 \text { control }}=4.00 ; p=.772$ ) and TI4 $\left(\mathrm{M}_{\text {TI4experiment }}=3.34 ; \mathrm{M}_{\mathrm{TI} 4 \mathrm{control}}=3.10 ; p=.499\right)$ show no significant difference statistically. However, the composite mean score between the two groups is significantly different.

\section{Discusion}

The result shows that indicator TI1 has the highest mean difference among the four indicators, and followed by indicator TI2. It means that after watching the reality show, the participants became aware of Zimbabwe as a tourism destination, also aware that Zimbabwe is an interesting place to visit. The result also indicates that participants who were exposed to the reality show, are interested to find more information about Zimbabwe than those who weren't. Although statistically not significant, participants in experiment group who watched the video stimulus have desire to visit and book vacation to Zimbabwe.

Shani et al., (2009) drawn this measurement from hierarchy of effect model, AIDA (attention/awareness, interest, desire, action) that commonly used in advertising to see the acceptance of advertisements by customers. This result indicates that after being exposed to the destination through reality show, attention/awareness of viewers toward the destination is triggered the most then followed by the interest. This founding is in line with the previous research. Kim and Richardson (2003) found that the exposure of Vienna city increased the intention of the participants to visit the city. Hudson et al., (2011) and Shani et al. (2009) both used Southern America as the object of the research and found that there was an increasing in travel intention of the participants, even though the result was not fully supported. Tessitore et al., (2014) also found that after watching the reality show the participants were interested to visit India.

Furthermore, the descriptive analysis of the participants showed that the income of the participants were around IDR 1,000,000,- and they expended around the same amount in a month. Hence, the participants which were students did not have sufficient income for themselves to travel abroad so easily. This could explain why the desire to visit the destination, moreover the action to book the ticket to go to Zimbabwe were not that high. However, a further research is needed to confirm this assumption.

\section{Conclusions}

This research found that those who watched the reality show, in overall, had higher travel intention to the destination displayed in the reality show than those who weren't. The participants which were students were assumed to have limited ability to decide to book a travel to faraway country, explained the indifference in desire and action to book a vacation between two groups. However, it still can be concluded that watching the reality show which showed real activities, expressions, emotions and landscapes of a destination, could trigger the travel intention of the viewer. This confirmed the argument of Croy and Walker (2003) that simply by seeing a 
destination displayed in media such as film or reality show, the viewers will have the intention to visit the destination.

The implication of this research is valuable for the tourism industry, in particular, the government of country or a city. Any form of media can be used to help promoting a destination. Reality show in specific is more flexible than film because of the nature of reality show itself, serves numbers of episodes and even seasons, hence the same destination can appear multiple times.

\section{References}

Barton, K. (2009). Reality Television Programming and Diverging Gratifications: The Influence of Content on Gratifications Obtained. J. Of Broadcasting \& Elec. Media, 53(3), 460-476. http://dx.doi.org/10.1080/08838150903102659

Blumler, J. \& Katz, E. (1974). The Uses of mass communications in Ruggiero, T. (2000). Uses and Gratifications Theory in the 21st Century. Mass Communication And Society, 3-37. http://dx.doi.org/10.1207/s15327825mcs0301_02

Brito, P. Q., \& Pratas, Joaquim. (2015). Tourism brochures: Linking message strategies, tactics, and brand destination attributes. Tourism Management, 48, $123-138$.

Connell, J. (2005). Toddlers, tourism and Tobermory: Destination marketing issues and television-induced tourism. Tourism Management, 26(5), 763-776. http://dx.doi.org/10.1016/j.tourman.2004.04.010

Croy, G., \& Walker, R. D. (2003). Rural tourism and film - issues for strategic rural development. Dalam Connell, J. (2012). Film tourism - Evolution, progress and prospects. Tourism Management, 33(5), 1007-1029. http://dx.doi.org/10.1016/j.tourman.2012.02.008

Dimanche, F. \& Andrades Caldito, L. Tourism in Russia.

Fu, H., Ye, B., \& Xiang, J. (2016). Reality TV, audience travel intentions, and destination image.Tourism 37-48. http://dx.doi.org/10.1016/j.tourman.2016.01.009

Hudson, S., Wang, Y., \& Gil, S. (2010). The influence of a film on destination image and the desire to travel: a cross-cultural comparison. International Journal Of Tourism Research, n/a-n/a. http://dx.doi.org/10.1002/jtr.808

Jang, S. \& Namkung, Y. (2009). Perceived quality, emotions, and behavioral intentions: Application of an extended Mehrabian-Russell model to restaurants. Journal of Business Research, 62(4), 451-460. http://dx.doi.org/10.1016/j.jbusres.2008.01.038

Jang, S., Bai, B., Hu, C., \& Wu, C. (2009). Affect, travel motivation, and travel intention: a Senior market. Journal of Hospitality and Tourism Research, 33(51), http://jht.sagepub.com/content/33/1/51.refs.html

Kerstetter, D. \& Cho, M. (2004). Prior knowledge, credibility and information search. Annals Of Tourism Research,31(4), 961-985. http://dx.doi.org/10.1016/j.annals.2004.04.002

Kim, H. \& Richardson, S. (2003). Motion picture impacts on destination images. Annals Of Tourism Research,30(1), 216-237. http://dx.doi.org/10.1016/s0160-7383(02)00062-2 
Journal of Educational Method and Technology Vol. 2 No. 2, Agustus 2019

P-ISSN 2622-8459 E-ISSN 2622-8467

http://ejournal.unima.ac.id/index.php/jemtec

Kim, S., Agrusa, J., Lee, H., \& Chon, K. (2007). Effects of Korean television dramas on the flow of Japanese tourists. Tourism Management, 28(5), 1340-1353. http://dx.doi.org/10.1016/j.tourman.2007.01.005

Kumar, P. (2014). Role of Media in The Promotion of Tourism Industry in India. Online International Research Journal, 1(3).

Lee, C. \& Chang, C. (2008). Tourism development and economic growth: A closer look at panels. Tourism Management, 29(1), 180-192. http://dx.doi.org/10.1016/j.tourman.2007.02.013

Lin, Y. S., \& Huang, J. Y. (2006). Internet blog as tourism marketing medium: A Case study. Journal of Business Research, 59, 1201 - 1205.

MacKay, K. \& Fesenmaier, D. (1997). Pictorial element of destination in image formation. Annals Of Tourism Research,24(3), 537-565. http://dx.doi.org/10.1016/s0160-7383(97)00011-x

Nabi, R., Biely, E., Morgan, S., \& Stitt, C. (2003). Reality-Based Television Programming and the Psychology of Its Appeal. Media Psychology, 5(4), 303-330. http://dx.doi.org/10.1207/s1532785xmep0504_01

Nezakati, H., Amidi, A., Jusoh, Y. Y., Moghadas, S., Aziz, Y. A., \& Sohrabinezhadtalemi, R. (2015). Review of social media potential of knowledge sharing and collaboration in tourism industry. Procedia-Social and Behavioral Sciences, 172, 120-125

Nirwandar, S. (2014). Building WOW Indonesia Tourism and Creative Industry. Jakarta: PT. Gramedia Pustaka Utama.

Riley, R. \& Van Doren, C. (1992). Movies as tourism promotion. Tourism Management, 13(3), 267-274. http://dx.doi.org/10.1016/02615177(92)90098-r

Riley, R., Baker, D., \& Doren, C. (1998). Movie induced tourism. Annals of Tourism Research, 25(4), 919-935. http://dx.doi.org/10.1016/s0160-7383(98)00045-0

Shani, A., Wang, Y., Hudson, S., \& Gil, S. (2009). Impacts of a historical film on the destination image of South America. Journal Of Vacation Marketing, 15(3), 229-242. http://dx.doi.org/10.1177/1356766709104269

Tessitore, T., Pandelaere, M., \& Van Kerckhove, A. (2014). The Amazing Race to India: Prominence in reality television affects destination image and travel intentions. Tourism Management, 42, 3-12. http://dx.doi.org/10.1016/j.tourman.2013.10.001

Tooke, N. \& Baker, M. (1996). Seeing is believing: the effect of film on visitor numbers to screened locations. Tourism Management, 17(2), 87-94. http://dx.doi.org/10.1016/0261-5177(95)00111-5

Tooke, N. \& Baker, M. (1996). Seeing is believing: the effect of film on visitor numbers to screened locations. Tourism Management, 17(2), 87-94. http://dx.doi.org/10.1016/0261-5177(95)00111-5

United Nation World Tourism Organization (2019). International Tourism Results 2018 and Outlook 2019.

United Nation World Tourism Organization (2019). UNWTO World Tourism Barometer, 17(1).

Wong, J. (2001). Here's looking at you: Reality TV, Big Brother, and Foucault. Canadian Journal Of Communication, 26, 33-501. 
Journal of Educational Method and Technology Vol. 2 No. 2, Agustus 2019

P-ISSN 2622-8459 E-ISSN 2622-8467

http://ejournal.unima.ac.id/index.php/jemtec

World Travel\& Tourism Council. (2019).Travel \& Tourism : Economic Impact 2015-Indonesia. http://www.wttc.org/

Zhang, H., Fu, X., Cai, L., \& Lu, L. (2014). Destination image and tourist loyalty: A meta-analysis.Tourism Management, 40, 213-223. http://dx.doi.org/10.1016/j.tourman.2013.06.006 